\title{
Experimental Analysis of Impact on Quality \& Quantity of Water Bodies in Chennai
}

\author{
Dr.A.S.Kanagalakshmi ${ }^{1}$, Gokul Sudharsan.P ${ }^{2}$, Ranjith. ${ }^{2}$, \\ Mohammed Saleem Badhusha. ${ }^{2}$, Sanjay Krishnan. $\mathrm{S}^{2}$ \\ ${ }^{1}$ (Prof. in Panimalar engineering college) \\ ${ }^{2}$ (students of panimalar engineering college)
}

\begin{abstract}
Rapid urbanization throughout the world leads to pressure on infrastructure development for planners. The provision of clean water, treatment and disposal of wastewater has become a challenge to water resources and environmental engineers. It is perceived that new approaches will reduce the water stress and can contribute markedly to improve the availability of water. This research work relates to water management aspects of Chennai Metropolitan Area (CMA), Tamil Nadu state in its entirety to suggest effective measures for improvement. Chennai Metropolitan Area spread over $1172 \mathrm{sq} . \mathrm{km}$. with a population of about 6.6 million consists of Chennai city, 13 municipalities, 23 town panchayats and 214 village panchayats of which 18 were classified as census towns. Chennai city's water supply is governed by the Chennai Metropolitan Water Supply and Sewarage Board and Tamil Nadu Water Supply and Drainage Board looks after the water supply aspects in Municipalities, Town Panchayats and Village Panchayats of Chennai Metropolitan Area. A detailed literature review regarding water demand and supply, wastewater management and stormwater management are carried out. Water scarcity, water quality determination, inadequate institutional capacity, lack of comprehensive regulation and financial constraints are some of the aspects that need to be looked into to develop plan for further investigation. Essentially this study indicates the opportunity for creating additional storages, making use of the available tank storages, additional water treatment plants with its location, to utilize the, Veeranam water, Poondi, chembarampakkam, cholavaram waters within Chennai Metropolitan Area suitably. Various technical investigations essential for planning water resources development activities for Chennai Metropolitan Area are indicated. This will serve as the starting point for the long term development of water management policies for this area.
\end{abstract}

Keywords: Tamilnadu Water supply And Drainage Board (TWAD BOARD), Mean Sea Level (MSL), Capacity, Catchment area, Chennai Metropolitan Area (CMA), Hard-rock run-off percolates areas

\section{Introduction}

Chennai city, the capital of Tamilnadu state, is located on the coast of the Bay of Bengal at latitude $13^{\circ} 4$ " North and Longitude $18^{\circ} 15^{\prime \prime}$ East. The terrain of the city is generally low lying and flat coastal plain known as the Eastern Coastal Plains, with an average slope of less than 1/1500. Most of the places are within 4 $\mathrm{m}$ to 5 metres above Mean Sea Level (MSL), its highest point being $60 \mathrm{~m}$. The Chennai Corporation was expanded from $174 \mathrm{~km} 2$ (67 sq mi) to an area of $426 \mathrm{~km} 2$ (164 sq mi), dividing into three regions-North, South and Central. The Current Population of Chennai in 2016 is 8,233,084 (8.2 million).

The geology of Chennai comprises mostly clay, shale and sandstone. The city is classified into three regions based on geology, sandy areas, clayey areas and hard-rock areas. Sandy areas are found along the river banks and the coasts. Clayey regions cover most of the city. Hard rock areas are Guindy, Velachery, Adambakkam and a part of Saidapet. In sandy areas rainwater run-off percolates very quickly. In clayey and hard rock areas, rainwater percolates slowly, but it is held by the soil for a longer time. 


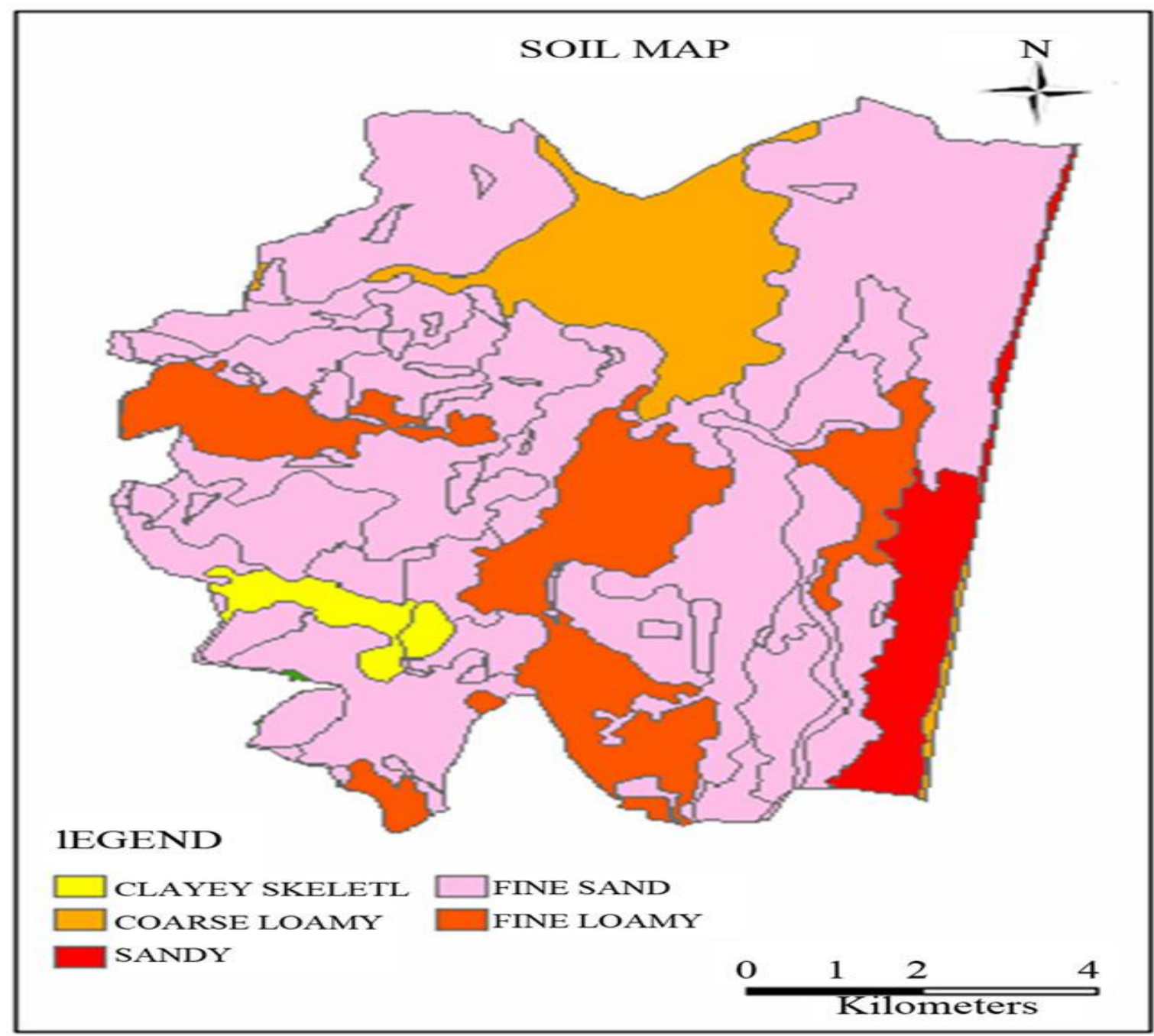

\section{Water Resources In Chennai}

Two rivers meander through Chennai, the Cooum River in the central region and the Adyar River in the southern region. Both rivers are heavily polluted with effluents and trash from domestic and commercial sources. The Adyar, which is much less polluted than the Cooum, is de-silted and cleaned periodically by the state government. A protected estuary of the Adyar forms the natural habitat of several species of birds and animals. The Buckingham Canal, $4 \mathrm{~km}$ inland, travels parallel to the coast,linking the two rivers. The OtteriNullah, an east-west stream runs through north Chennai and meets the Buckingham Canal at Basin Bridge. Several lakes of varying size are located on the western fringes of the city.

Poondi,Cholavaram, Red Hills and Chembarampakkam lakes supply Chennai with potable water. Groundwater sources are mostly brackish. Surface water sources such as reservoirs at Poondi, Cholavaram, Redhills, Chembarampakkam, Veeranam Lake, RettaiEri, Porur Lake and Kandaleru Reservoir in Andhra Pradesh under Krishna water supply scheme are the main sources of water supply for Chennai city and the adjacent urban areas. The main source of supply for Poondi, Cholavaram, Redhills and Chembarampakkam reservoir is the river Korataliyar across which Poondi reservoir is constructed. Tamarapakkamanicut across the river located $30 \mathrm{~km}$ downstream of Poondi serves to divert the flows through the upper supply channels to Cholavaram tank which in turn is linked to Redhills by the lower supply channel. From Redhills tank, raw water is conveyed through conduits to Kilpauk water works where water is treated and supply to north Chennai city. Through link canal water from Poondi reservoir is diverted to the Chembarampakkam tank from where water is treated and supplied to south Chennai city. 


\section{WATER RESOURCES MAP OF CHENNAI}
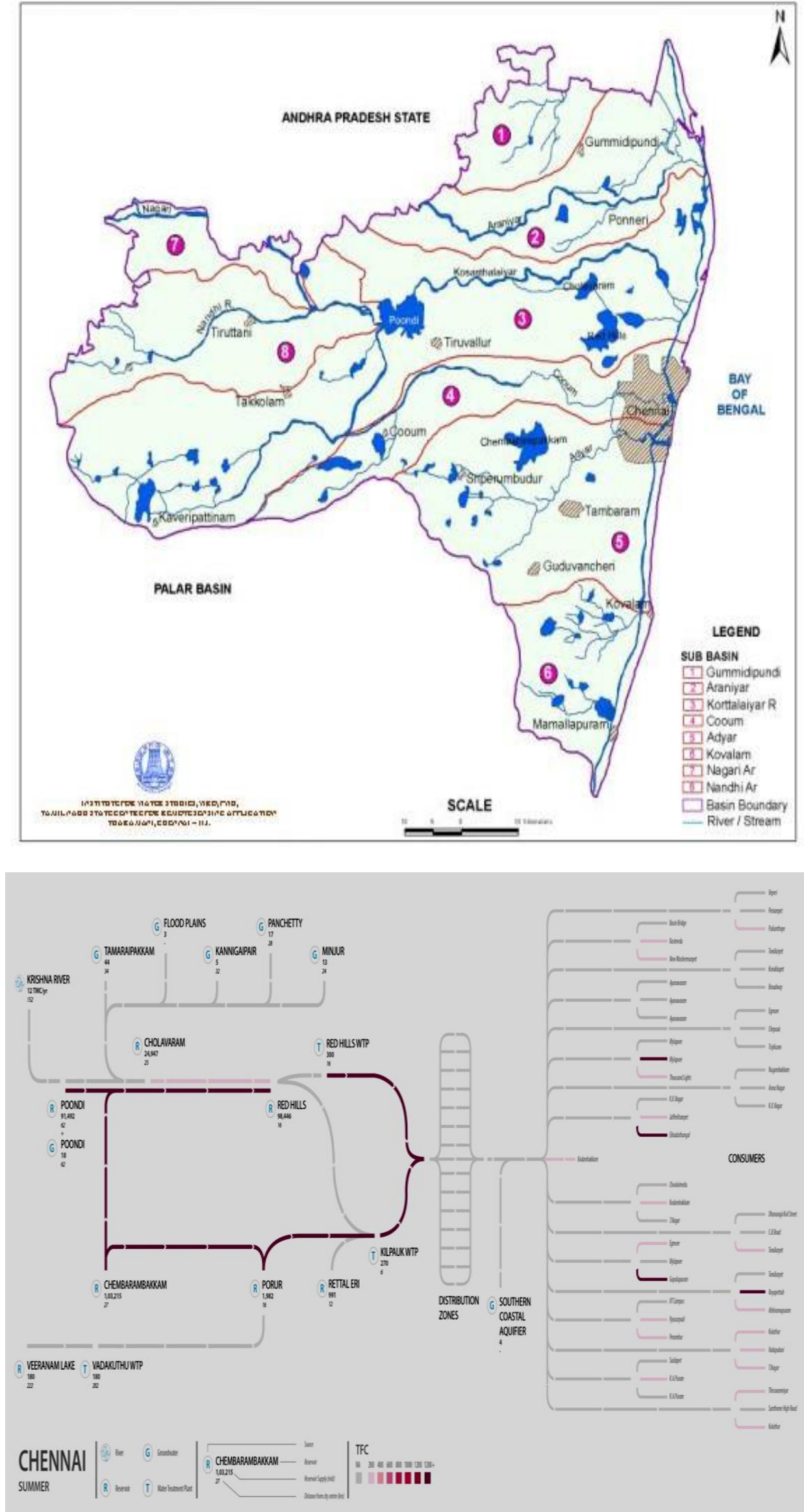


\section{POONDI}

Poondi reservoir plays an important role since this reservoir receives the Krishna water from Kandaleru reservoir through KandaleruPoondi canal whose capacity is $28.34 \mathrm{~m} 3 / \mathrm{s}$ (1000 cusecs). The inflow into Poondi reservoir consists of the inflow from Nandi and Nagari rivers, diversion from Kesavaramanicut, release from Kandaleru reservoir and its own catchment area. The free catchment of Poondi reservoir is $1968 \mathrm{~km} 2$. As a part of Krishna water supply project, the full reservoir level (FRL) of Poondi reservoir is raised by $0.60 \mathrm{~m}$ above the present FRL $42.7 \mathrm{~m}$. Hence the gross storage capacity is increased to $98.07 \mathrm{Mm} 3$ (3460 Mcft) from $78.00 \mathrm{Mm} 3$ (2750 Mcft) and the live storage capacity to $97.80 \mathrm{Mm} 3$ (34.50 Mcft) from $77.66 \mathrm{Mm} 3$ (2740 Mcft) from this reservoir, water will be released to Cholavaram tank, Redhills tank, and Chembarampakkam tank. The spill flows through Tamarapakkamanicut through the river reach.

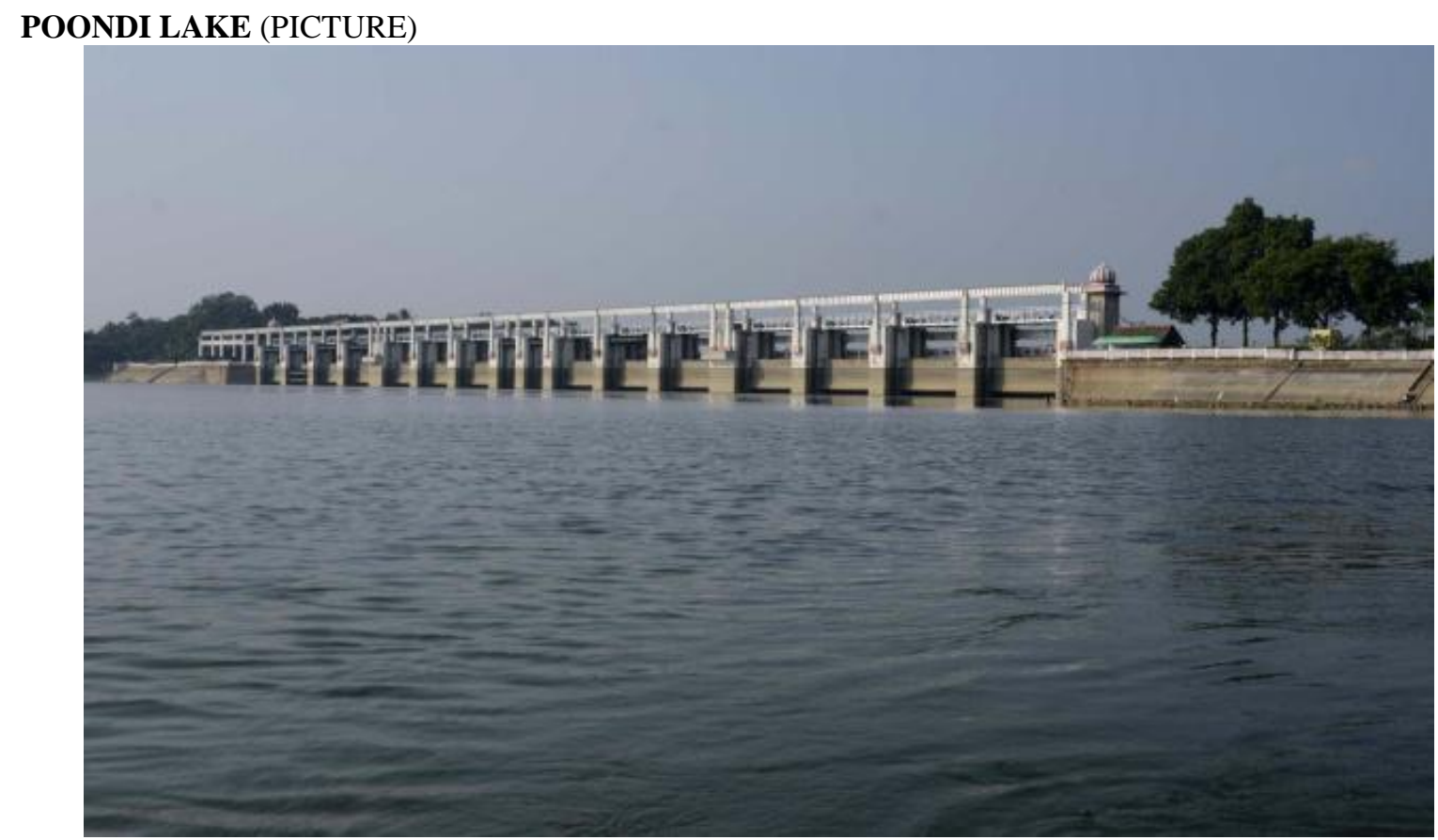

\section{CHOLAVARAM}

The inflow into Cholavaram tank consists of inflow due to the release from Poondi reservoir, diversion from Tamarapakkamanicut trough the upper supply channel, and inflow from its own catchment area. The free catchment area for Cholavaram tank is $28.16 \mathrm{~km}^{2}$. The gross storage capacity of Cholavaram tank is $25.20 \mathrm{Mm} 3$ ( $889 \mathrm{Mcft}$ ) of which the live storage capacity is $23.55 \mathrm{Mm}^{\wedge} 3$ (631 Mcft). From this tank water will be released to Redhills tank through lower supply channel.

\section{CHOLAVARAM LAKE (PICTURE)}

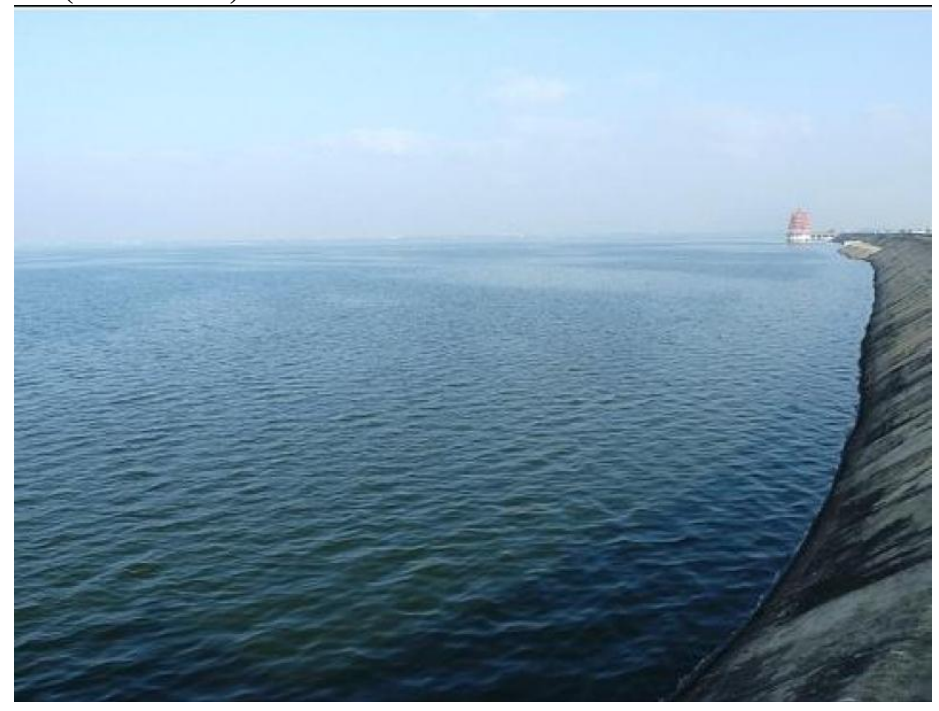




\section{REDHILLS}

The Redhills tank supplies water through closed conduits to Kilpauk water works for treatment and supply to North Chennai city. The inflow into the tank consists of release from Poondi reservoir through the link canal and then through feeder canal, release from Cholavaram tank and its inflow from its own catchment area. The free catchment area for Redhills tank is $37.955 \mathrm{~km}^{2}$. Under the proposed system, the full tank level (FTL) of this tank is raised by $0.60 \mathrm{~m}$ above the present FTL, thereby increasing the gross storage capacity from 80.78 $\mathrm{Mm}^{\wedge} 3$ (2850 Mcft) to $93.54 \mathrm{Mm}^{\wedge} 3$ (3300 Mcft) and the live storage capacity from $7.12 \mathrm{Mm}^{\wedge} 3$ (2509 Mcft) to $8387 \mathrm{Mm}^{\wedge} 3(2959 \mathrm{Mcft})$.

\section{REDHILLS LIKE (PICTURE)}

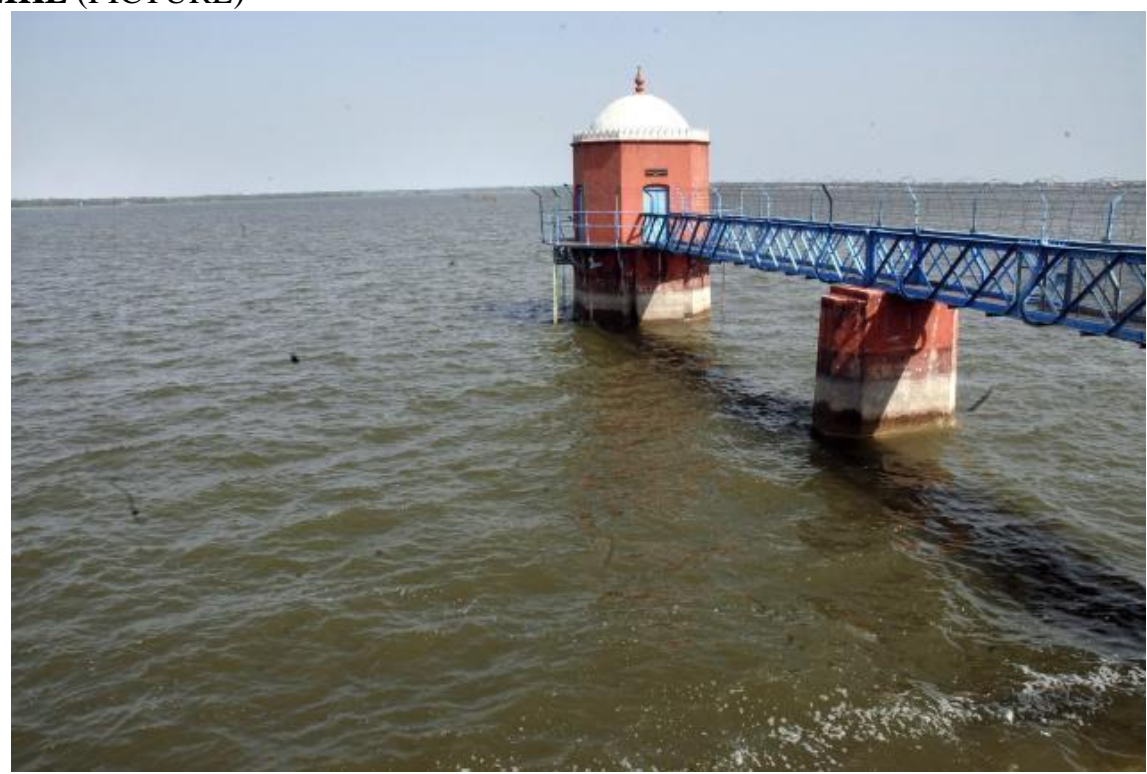

\section{CHEMBARAMPAKKAM}

The Chembarampakkam tank supplies water to the south Chennai city since 2001. Before that it was supporting irrigation in the surrounding areas. The inflow into this tank consists of the inflow due to the release from Poondi reservoir, diversion from Koratturanicut and the inflow from its own catchment area. The free catchment for Chembarampakkam tank is $77.10 \mathrm{~km}^{2}$. The Full tank capacity of this tank is proposed to raise by $0.60 \mathrm{~m}$ above the present FTC of $25.43 \mathrm{~m}(83.40 \mathrm{ft})$. Hence the gross as well as the live storage capacity is to go from 88.44 Mm3 (3120 Mcft) to $103.32 \mathrm{Mm} 3$ (3645 Mcft).

\section{CHEMBARAMPAKKAM LAKE (PICTURE)}

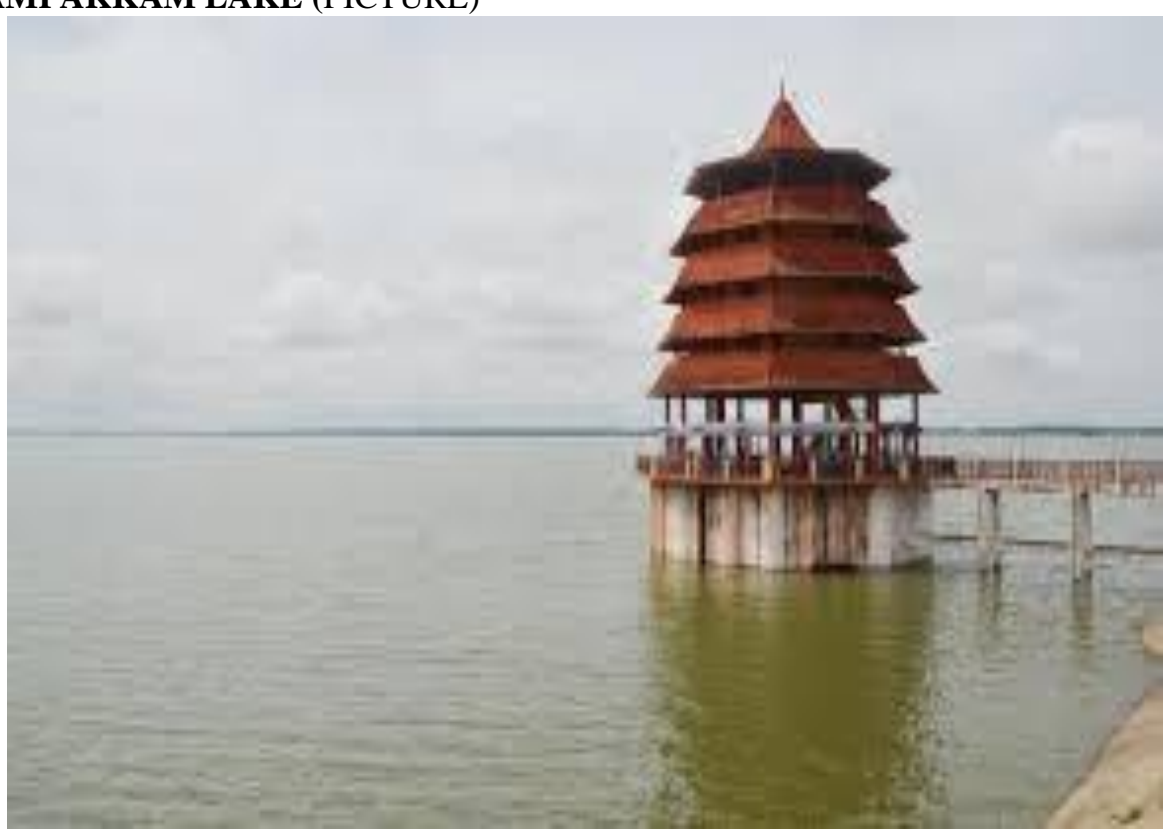




\section{VEERANAM}

The Veeranam Water Supply Project was implemented as additional source of water to Chennai city and is aimed at bringing water from Veeranam Lake situated about $235 \mathrm{~km}$ south of Chennai in Cuddalore district. This lake receives water from Cauvery River system through Kollidam, Lower Anicut and Vadavar Canal besides rainwater from its own catchment area. The capacity of the lake is $41.48 \mathrm{Mm} 3$ (1465 Mcft). The lake water is treated at Vadakuthu Water Treatment Plant by pumping raw water at a distance of $20 \mathrm{~km}$ from Sethiathope to Vadakuthu through $1775 \mathrm{~mm}$ diameter mild steel pipe. The treated water is then pumped at a distance of $8 \mathrm{Km}$ to Break Pressure Tank at Kadampuliyur through $1750 \mathrm{~mm}$ diameter mild steel pipe and from there the water is conveyed to a distance of about $200 \mathrm{Km}$ through the mild steel pipe of $1875 \mathrm{~mm}$ and $1500 \mathrm{~mm}$ diameter by gravity to Porur Water Distribution Station near Chennai. From Porur Water Distribution Station, water is pumped to a distance of $1.2 \mathrm{~km}$ and distributed to Chennai city through Trunk mains and Water Distribution Stations.

Veeranam water supply project would bring about 180 MLD to Chennai city. This is about one third requirement of water in Chennai city per day. The full supply of 180 MLD of water to Chennai city through the New Veeranam Project commenced on 13.10.2004 has greatly reduced dependency on distant sources. During the years of deficit rainfall, water in the Veeranam Lake may not be sufficient. Hence, it was decided to implement a project called the New Veeranam Extension Project to draw sub surface water in Kollidam riverbed and pump the same to Sethiathope and then to Chennai through the New Veeranam Project infrastructure. The proposed scheme is to draw 150 MLD sub surface water from the Kollidam river by constructing 6 Nos. of collector wells between mileages $39 / 3$ and 59/0 in the Kollidam river. This proposal envisages that the water from the Collector Wells will be pumped to a sump and then conveyed by the pipeline to Sethiathope raw water pumping station constructed under the Chennai water supply augmentation project (New Veeranam Project) for onward transmission to Chennai city through the pumping and pipeline arrangements of Chennai water supply augmentation project.

\section{VEERANAM WATER CHANNEL MAP}

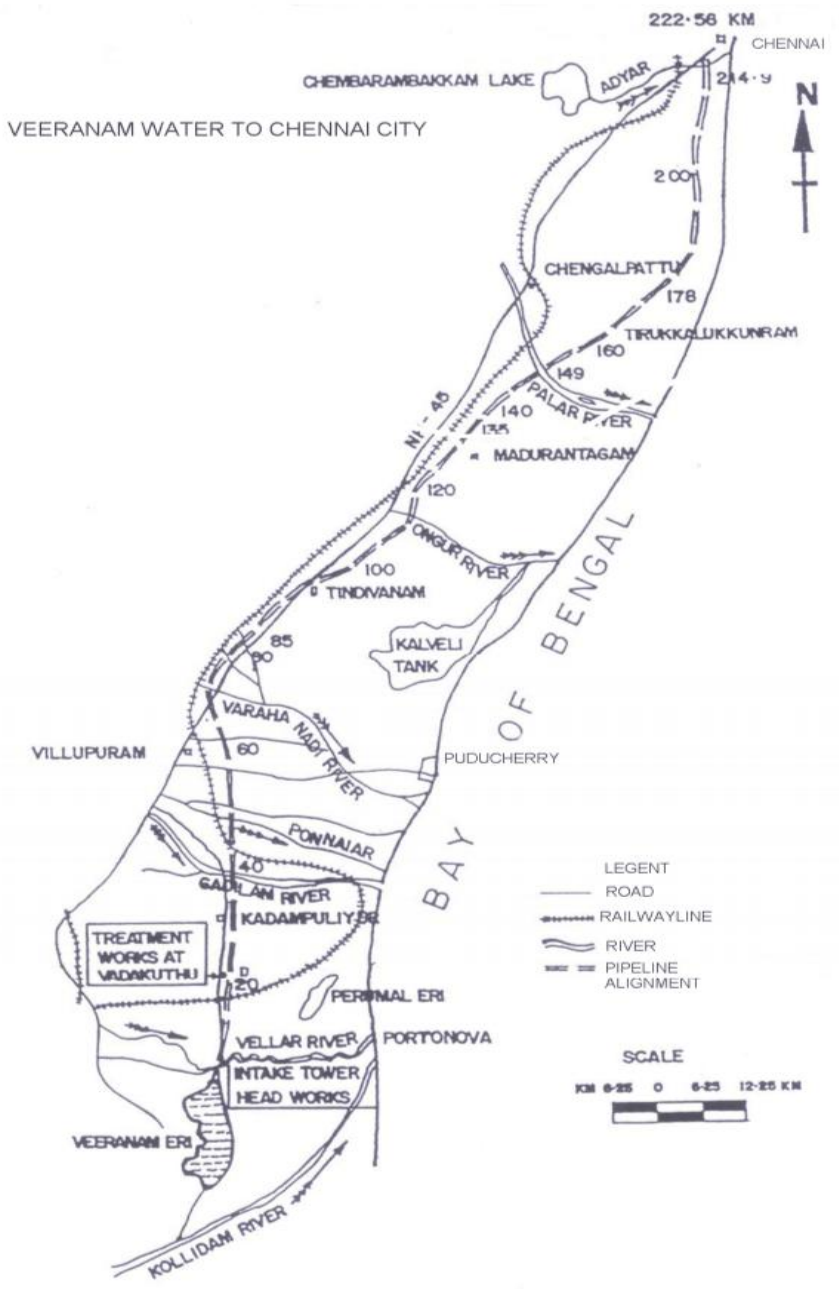




\section{KRISHNA WATER SUPPLY PROJECT}

As per this project, water is drawn from the Srisailam reservoir when Krishna river is in flood in the month of July-October and January-April and conveyed to the Somasila reservoir on Pennar river through an open channel. A reservoir at Kandaleru is linked to the Somasila reservoir by another canal. From Kandaleru reservoir a canal is run to Poondi reservoir. This gravity canal flow system backed up by large reservoirs at Srisailam, Somasila and Kandaleru will enable drawing and holding the flood flows for irrigation an extent of 2.33 lakh hectares in Andhra Pradesh and a regulatedsupply of $340 \mathrm{Mm} 3$ (12 TMC) of water per annum at the Tamilnadu border for Chennai city water supply. During the months from July to October $21.33 \mathrm{~m} 3 / \mathrm{s}$ will be delivered and during the months from January to April $10.93 \mathrm{~m} 3 / \mathrm{s}$ will be delivered. Andhra Pradesh released Kandaleru water for the first time on 29.9.1996. Further, for the first time, water received under Krishna Water Supply Project was conveyed to Chembarampakkam Lake during January 2007.

During 2006-2007, water was received from Kandaleru reservoir in Andhra Pradesh under Krishna Water Supply Scheme in two spells i.e. 2.869 TMC from 19.08.2006 to 06.11.2006 and 2.315 TMC from 14.12.2006 to 08.02.2007 and the total quantity received is 5.184 TMC. This helped in maintaining the city water supply continuously at the rate of about 645 MLD even though the inflow in the reservoirs due to the Northeast monsoon was not appreciable.

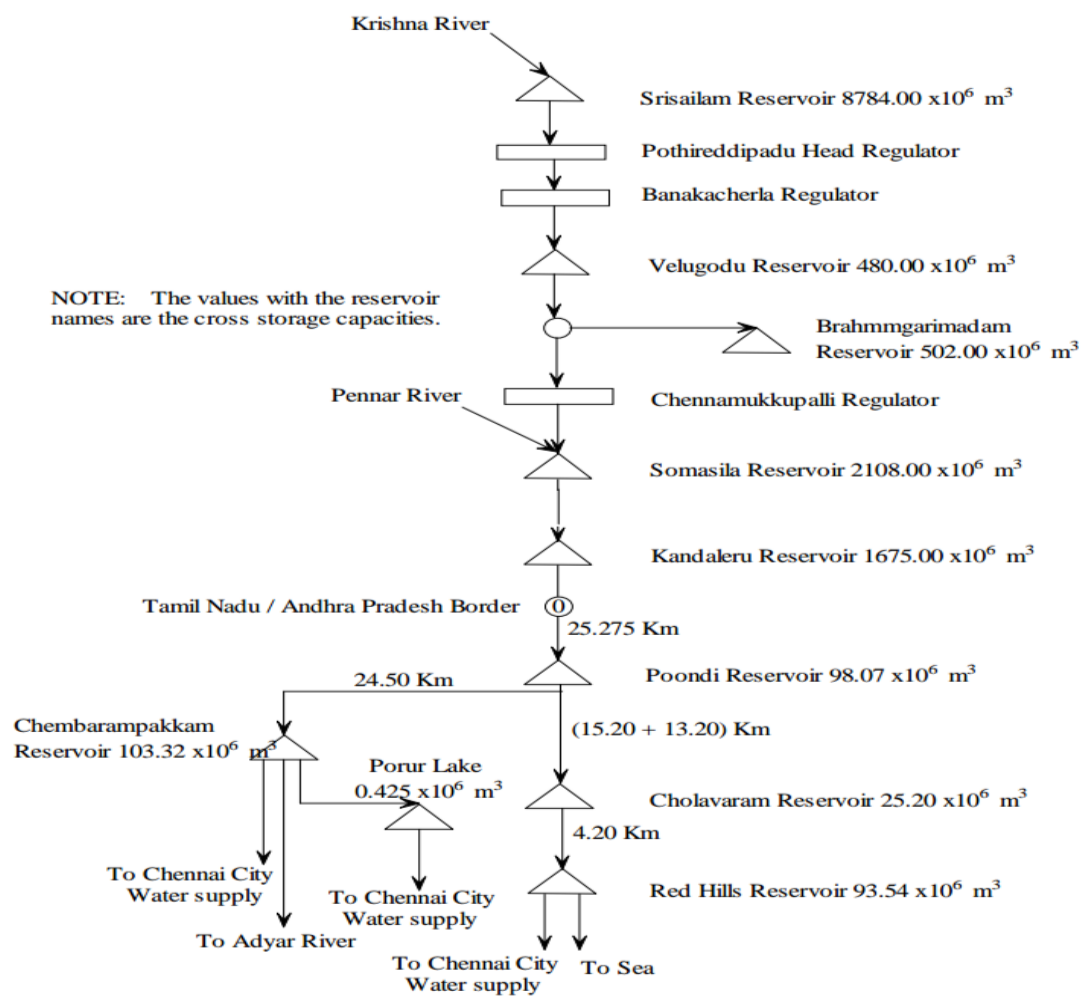

CHENNAI CITY'S EXISTING WATER SUPPLY RESERVOIRS

\begin{tabular}{|c|c|c|c|c|c|}
\hline Name of Reservoir & $\begin{array}{l}\text { FullTank } \\
\text { Level (m) }\end{array}$ & $\begin{array}{l}\text { Storage at sill } \\
\text { level }\left(\mathrm{Mm}^{\wedge} 3\right)\end{array}$ & $\begin{array}{l}\text { Water spread area } \\
\text { at sill level }\left(\mathrm{Mm}^{\wedge} 2\right)\end{array}$ & $\begin{array}{l}\text { Storage at } \\
\text { F.T.L }\left(\mathrm{Mm}^{\wedge} 3\right)\end{array}$ & $\begin{array}{l}\text { Water spread area } \\
\text { at F.T.L }\left(\mathrm{Mm}^{\wedge} 2\right)\end{array}$ \\
\hline Poondi & 42.06 & 0.28 & 0.12 & 98.07 & 10.79 \\
\hline Cholavaram & 19.66 & 0 & 0.67 & 25.2 & 6.56 \\
\hline Red hills & 14.69 & 9.67 & 2.09 & 93.54 & 21.55 \\
\hline Chembarambakkam & 26.04 & 0 & 0 & 103.32 & 25.57 \\
\hline Total & & 11.54 & 2.88 & 320.13 & 64.41 \\
\hline
\end{tabular}

Total Population In Chennai = 8.6 Million

\section{Quantity Analysis}

Per Capita Demand $=135 \mathrm{MLD}$

Average Water Required $=8.6 \times 135 \times 10^{12}=1161 \times 10^{12}$ litre

Total Quantity of Water available from Reservoir $=8367 \mathrm{Mcft}=236.927 \times 10^{9}$ litre

THIS CONCLUDES THAT THE WATER AVAILABLE FROM THE WATER RESOURCES NEAR CHENNAI IS NOT SUFFICIENT TO MEET THE NEED OF THE PEOPLE IN CHENNAI. 


\section{Conclusion}

The water level is now at an average of 4.70 metre, which is 0.5 metre lower than last year, according to a study conducted by Metrowater. The prolonged dry weather and inadequate rains have led to the drop in the water table. Residents of several years are heavily dependent on tanker lorry supply as the water level in their wells has dipped and also turned saline in some pockets such as Okkiyam Thoraippakam and Ambattur. Residents of Ambattur said borewells were being dug deeper to cope with the shortage.According to a Metrowater official, the water table in some areas such as Valrasaravakkam, Ambattur and Perungudi has seen the worst dip this May. The ground in these areas is composed of hard rock and clay that make percolation of water difficult.The water levels vary depending on the soil condition and density of population. The quality of groundwater too has deteriorated. The total dissolved solids in the water ranged between 900 and 1,900 parts per million (ppm) - $200 \mathrm{ppm}$ more than last year - in various localities. The desired limit for drinking water is $500 \mathrm{ppm}$. (Metrowater collates data collected from 145 observation wells for its monthly study.)

Though there are many water resources bound with Chennai, due to various factors like Population, Pollution and Improper rainfall there is a Water Scarcity every year. As the population growth is high, the sewage is mixed with fresh water which leads to major water scarcity in Chennai.

The remedial measures may include the treatment of sewage water without getting mixed with underground water and from edible water.The cleaning of the river coovum and adyar will be effective measure to reduce the scarcity. The installation of many desalination plants also reduces the water scarcity. Treating and reusing of non-toilet waste water from the building will surely be a effective way as the water requirement for the building would to reduced.

\section{Acknowledgements}

It gives us immense pleasure to be associated with the project. The project was a joyous learning process.

We express our sincere thanks to our Principal Dr.Mani, for extending all the facilities needed to carry out this project work.

We also express our gratitude to Dr.M.MAGESWARI, Head Of The Civil Engineering Department, civil enginnering department, Panimaler engineering college for her invaluable guidance and technical support throughtout the project work.

We would like to express our gratitude to Dr.A.S.Kanagalakshmi, civil engineering department, panimalar engineering college for her technical support throughtout the project $\&$ journal work.

We are very much thankful to all our staff member of civil engineering department who have been kind enough to help us in completing this project.we would also thank our class mates for their help during the project \& journal work.

\section{References}

[1]. Chennai government of Tamil Nadu http://www.cmdachennai.gov.in

[2]. Chennai Metropolitan Water Supply and Sewerage Board (CMWSSB) in Tamilnadu http://www.chennaimetrowater.gov.in

[3]. Population of Chennai city http://www.census.co.in

[4]. CWC/MWR (Central Water Commission, Ministry of Water Resources). 2005. Rainfall in different meteorological zones of India

[5]. Environmental Planning Frame Work for Water Resources Management in Tamil Nadu, Public Works Department. Government of TamilNadu.

[6]. Ground Water Resources of Tamil Nadu,2002,Public Works Department. Government of TamilNadu.

\section{Books:}

[7]. Jain SK, Agarwal PK and Singh VP 2007. Hydrology and water resources of India (Dordrecht, Netherlands: Springer)

[8]. National Water Policy, 2002. Government of India, Ministry of WaterResources. New Delhi, April, 2002.

[9]. Central Water Commission [CWC] (2010), 'Preliminary Consolidated Report on Eff ect of Climate Change on Water Resources', Government of India, available at: http://cwc.gov.in/main/downloads/Preliminary_Report_fi nal.pdf

[10]. "Historical Background" Chennai Metro Water.

\section{Proceedings Papers:}

[11]. Srinivasan, M. S. (15 September 2003). "Desalination: Answer to Chennai's water woes". Business Line. Chennai: The Hindu.

[12]. Lakshmi, K. "Metrowater to fathom needs of merged areas". The Hindu. Chennai: The Hindu. 